\title{
Organic Power Generation and Utilization Using Anaerobic Digestion Process
}

\author{
Rizwan Tariq ${ }^{\text {a,b }}$, Rao M. Asif ${ }^{c}$, Ateeq Ur Rehman ${ }^{\text {d,e, }}$, Muhammad Abu Bakar Siddique ${ }^{c}$, Adeel Asad ${ }^{c}$, Shahzad \\ Ashrafe

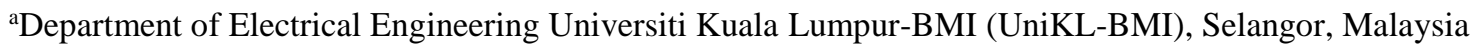 \\ bNational Power Construction Corporation Limited (NPCC), Dubai Branch, Jumeirah Lake Towers, UAE \\ ${ }^{\mathrm{c}}$ Faculty of Engineering and Technology, The Superior College (University Campus), Lahore, Pakistan \\ ${ }^{\mathrm{d}}$ Department of Electrical Engineering, Government College University, Lahore 54000, Pakistan \\ ${ }^{\mathrm{e}}$ College of Internet of Things Engineering, Hohai University, Changzhou Campus, Changzhou, China \\ *Corresponding Author Email: ateeq.rehman@gcu.edu.pk
}

\begin{abstract}
Organic power is produced by using both solids and liquid organic materials like wastage of industries, agriculture fields, and other synthetic materials. In recent days, many developed countries have given incentives for the production of bio-fuel and injected into the natural gas grid. The existing anaerobic digestion plants are upgraded to produce organic power efficiently. The objective of this paper is to introduce an innovative energy system for consuming organic materials. The proposed system is an anaerobic digestion system that consists of a digestion process tank, water tank, temperature controller for the digestion process, and other accessories to complete that process. An anaerobic digestion plant is developed as a function of the percentage of the organic materials sent to the upgrading system and the amount of organic power produced. The end products of the proposed system are biogas, biomethane, carbon dioxide, and clean fertilizer. The optimized parameters are taken as ammonia CODp, sugar TAN, proteins TOC, and organic inserts NORg. Furthermore, the comparison of organic fuels is discussed with other energy fuels.
\end{abstract}

Keywords- Organic power, Organic wastage, Anaerobic Digestion

Date Received 25-09- 2020

Date Accepted 20-10-2020

Date Published 18-12-2020

\section{INTRODUCTION}

$\mathrm{T}$ The energy crisis concerns the world's demand for the scarce natural resources needed to power industrial society are diminishing as the demand rises. In the past, there was only one resource to meet all energy requirements which was fossil fuel. Time by time the energy demand is increasing because of the growing population. The renewable energy resources are the only resources that can easily full fill the energy requirements and also reduce global warming as well [1]. The Sun is the only resource that has the potential to resolve all energy concerns forever [2]. The unavailability of the Sun is a big drawback of solar energy because of cloudy weather or night times. Wind energy is also a fuel-free source of energy but it is also dependent on weather conditions the same as solar power [3-4]. These serious effects on these two major resources are the reasons to move towards another energy resource that is organic power. Organic power is generated from the wastage of agriculture crops, wastage of municipal committees, food processing products, and any synthetic materials. So, much of the work has been done to increase crop productivity [5-9]. It's a major advantage that most of the products which may be natural or synthetic are made of organic compounds [10-12]. The conventional methods are landfilling or burning to treat the wastage. Though, there is some progress on automatic waste management to facilitate the citizens [13-17]. In recent days, the anaerobic digestion system is used for the composition of organic wastage for useful purposes. This process should be upgraded because this whole process happens in the open air and a lot of energy is wasted [18]. Most of the energy is produced by oxidation into carbon dioxide and water but it is not maximum use of organic wastage. The organic power from wastage is not a new step because many mini biogas projects are already installed in different countries. The governments of a few countries sponsored little projects which are used for heat and lightning. Microgrids are already installed that are feed by small farmhouses of villages [19-22]. Some of them are powered by a mixture of liquefied petroleum gas (LPG) and biomethane with the help of an internal combustion engine (ICE) [23-24]. Mostly organic power is produced by the wastage of any type of product because everything contains organic compounds. A suitable example of that scenario is a biogas plant that is powered by vegetables and fruit wastage of the cafeteria installed in the USA [25]. The biogas is also useful for the integration of multiple renewable resources as an economical resource. The reason for this integration is that the researchers and scientists are developing alternative energy resources [26, 27]. The economic and environmental concerns of conventional energy resources are motivating them to do it. Besides, the organic power from the wastage is going to be a very suitable option among other energy resources because the wind and solar energies are dependent on weather conditions. One more thing is that the growing population of the world has directly linked with wastage. The organic power from increasing wastage of the world is a very good choice.

In this paper, a digester tank is suggested for the breakdown of 
organic wastage. In that tank, all biochemicals are performed and its optimization is controlled by the monitoring and control section of this proposed scheme. In that section, different parameters are monitored and controlled like temperature, $\mathrm{PH}$ level, and water consumption. The weight bridge is inserted in our scheme for organic power estimation. The end products are biogas, biomethane, carbon dioxide, and clean fertilizer. The cost analysis between biogas and petroleum products is part of this work. In the end, the comparison between fuel production and distance traveled by vehicle with different fuels is also done.

\section{THE BASIC CONCEPT OF ORGANIC POWER}

The basic concept of organic power generation from the wastage is shown in Figure 1. In this diagram, it is mentioned that after the separation of unwanted materials from the wastage the material is sent to the digestion process tank. In the digestion process, these materials got free from heavy metals are digested without oxygen. This composition is formed by biochemical reactions and after the completion of the whole process, useful products including biogas, biomethane, carbon dioxide, and clean fertilizer are generated.

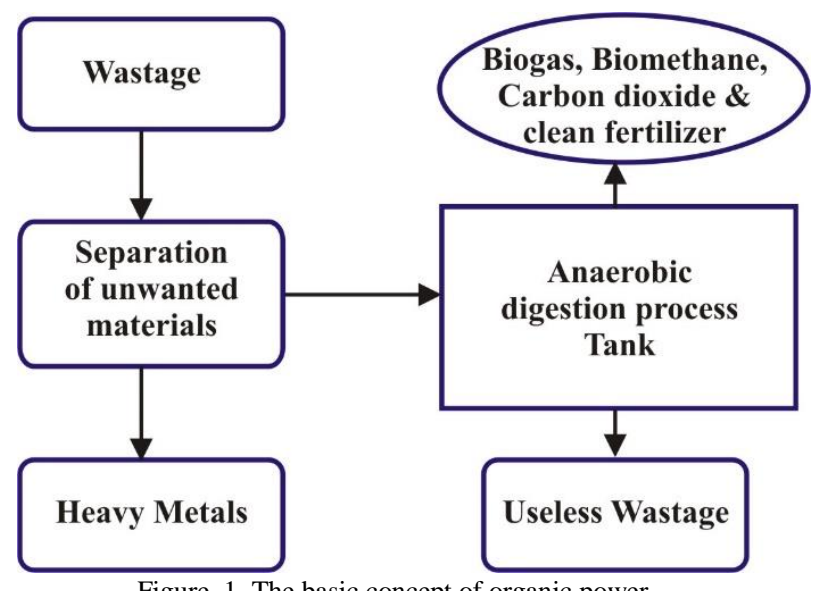

Figure. 1. The basic concept of organic power

\section{PROPOSED SCHEME FOR ORGANIC POWER}

The proposed scheme for organic power is shown in Figure 3. The main sections of the proposed process include waste handling, balancing of the digestion process, anaerobic digestion process, and wastage handling.

\section{A. Wastage Handling}

First of all waste handling is done for the conversion of organic wastage into energy. In this step, the materials are inserted in the tank, and then by weight bridge, the weight is measured. It is a useful phrase for organic power estimation and the filtration of useful materials. When the waste materials are settled down in the tank then floating materials are separated. In the last, the heavy materials like are also separated from wastage. Heavy materials are digested in the digestion process tank which is shown in Figure 3.

\section{B. Balancing of the digestion process}

This phase is very important for organic power production.
Balancing means the optimization of organic wastage and Table I consists of problems and their suggested action. In this process, the $\mathrm{PH}$ level, temperature, water consumption, and solids quantity are monitored.

TABLE I

OPTIMIZING STEPS FOR THE DIGESTION PROCESS

\begin{tabular}{|c|l|l|}
\hline Sr. No. & Serious Problems & Suggested Action \\
\hline 1 & Toxicity of Ammonia & $\begin{array}{l}\text { Add organic wastage } \\
\text { with a higher ratio of } \\
\text { organic materials. }\end{array}$ \\
\hline 2 & Reduction of Nutrients & $\begin{array}{l}\text { Start inserting chemical } \\
\text { nutrients or add wastage } \\
\text { with a higher ratio of } \\
\text { nutrients. }\end{array}$ \\
\hline 3 & Organic Overloading & $\begin{array}{l}\text { At PH=6.8, it means there } \\
\text { is an overloading of } \\
\text { organic materials. So, } \\
\text { add other wastage. }\end{array}$ \\
\hline 4 & Excess of solids & Add water or liquids. \\
\hline 5 & Toxic overloading & $\begin{array}{l}\text { Identify toxic materials } \\
\text { and separated them. }\end{array}$ \\
\hline
\end{tabular}

\section{Anaerobic Digestion Process:}

Biogas and waste materials are inserted in the digestion process tank in the absence of oxygen. In this tank, the breakdown of this wastage occurs. This breakdown happens with the metabolic process of the microbial population.

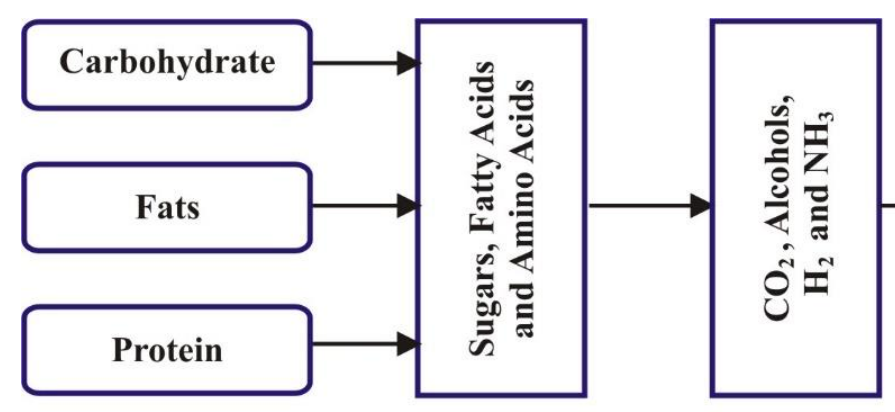

$$
\text { HYDROLYSIS }
$$

ACIDOGENESIS

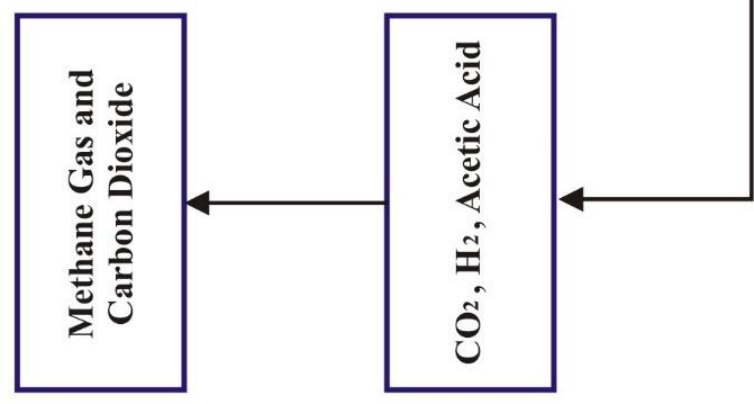

METHANOGENESIS ACETOGENESIS

Figure. 2. The stages of the anaerobic digestion process

Four groups of anaerobic bacteria are responsible for the compositions including hydrolytic bacteria, acetogenesis bacteria, homo acetogenic bacteria, and methanogenic bacteria. 


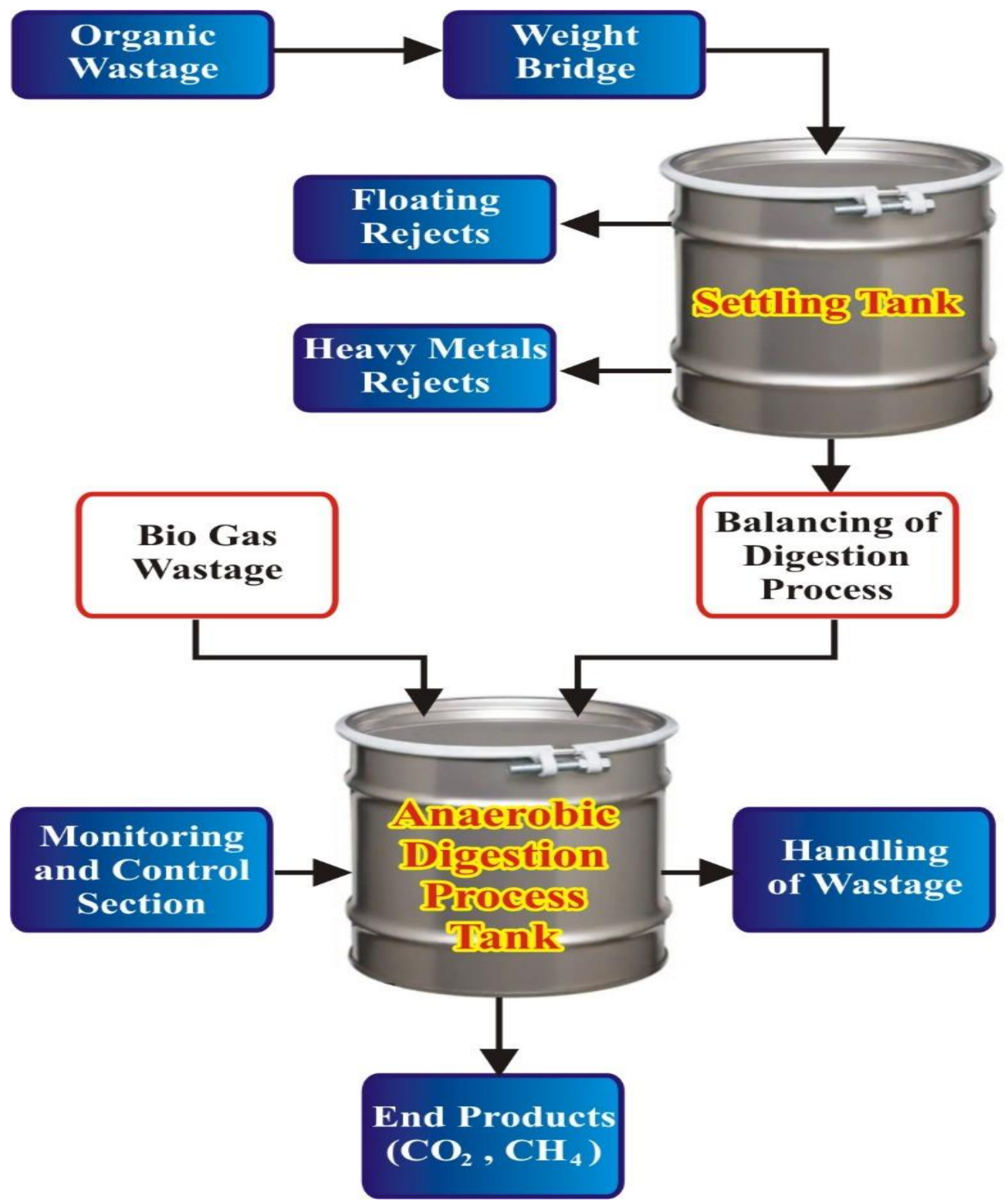

Figure. 3. The proposed scheme for organic power 
The waste calculation is estimated in Table II. The source of the collection is municipal solid waste, industrial solid waste, agricultural waste, urban wastewater from industrial and domestic sources, Wastage of hotels. The digestion process depends on the availability and supply of materials. The identification and quantification materials that are taken in the process have great importance. The feedstock is also discussed in table II.

TABLE II

DAILY WASTE ESTIMATION OF FEEDSTOCK

\begin{tabular}{|c|l|l|l|}
\hline $\begin{array}{c}\text { Sr. } \\
\text { No. }\end{array}$ & Wastage & Feedstock & $\begin{array}{l}\text { Daily } \\
\text { Collection }\end{array}$ \\
\hline 1 & $\begin{array}{l}\text { Organic-Solid } \\
\text { Wastage }\end{array}$ & $\begin{array}{l}\text { Municipal solid waste, } \\
\text { industrial solid waste, } \\
\text { agricultural waste, }\end{array}$ & 1.5 ton \\
\hline 2 & Organic Sludge & $\begin{array}{l}\text { urban wastewater from } \\
\text { industrial and } \\
\text { domestic sources }\end{array}$ & 1 ton \\
\hline 3 & Food Wastage & $\begin{array}{l}\text { Wastage of hotels and } \\
\text { fruit etc. }\end{array}$ & 1.5 ton \\
\hline 4 & $\begin{array}{l}\text { Animals } \\
\text { Manure }\end{array}$ & $8 \mathrm{Kg} /$ Animal & $80 \mathrm{~kg}$. \\
\hline
\end{tabular}

In the digestion process, the paraments are taken for processing's are total ammonia-nitrogen (TAN), volatile fatty acid (VFA), Total organic carbon (TOC), organic nitrogen (Norg), chemical oxygen demand (CODp), and total ammonianitrogen (TAN.) The estimated value of each is shown in table5 .

TABLE III

PARAMETERS OF DIGESTION PROCESS AND ESTIMATED VALUES

\begin{tabular}{|c|c|c|c|c|c|}
\hline \multirow{2}{*}{$\begin{array}{c}\text { Converted } \\
\text { items in the } \\
\text { Digestion } \\
\text { process }\end{array}$} & \multirow[b]{2}{*}{ 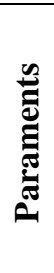 } & \multicolumn{2}{|l|}{ TAN } & Norg & CODp \\
\hline & & $\begin{array}{l}\overparen{r} \\
\overbrace{00}^{Z}\end{array}$ & 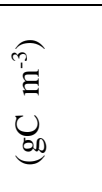 & 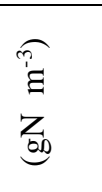 & 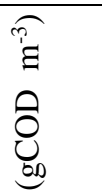 \\
\hline \multicolumn{2}{|l|}{ ammonia } & 0 & 0 & 0 & -1.29 \\
\hline \multicolumn{2}{|l|}{ Sugars } & -1 & -0.341 & 0 & 0 \\
\hline \multicolumn{2}{|l|}{ proteins } & 0 & -2.43 & 0 & 0 \\
\hline \multicolumn{2}{|c|}{ organic inserts } & 0 & -0.311 & 0.9 & -0.876 \\
\hline
\end{tabular}

The organisms of hydrolytic bacteria are proteins and lipids. The functioning of four processes completes the whole process which is shown in Figure 2. It starts from the hydrolysis, where the carbohydrates, fats, and proteins are converted into sugars, fatty acids, and amino acids. These converted products are further changed into carbonic acids, alcohols, ammonia and carbon dioxide in the acetogenesis process.

In the third phase of acetogenesis, these acids and alcohol products are converted into hydrogen acetic acids and carbon dioxide. The last phase is methanogenesis where methane gas and carbon dioxide are produced. The whole biochemical reaction is finally discussed in the following equation as [28].

Organic materials + water + nutrient $\longrightarrow \mathrm{CO}_{2}+\mathrm{CH}_{4}$ $+\mathrm{NH}_{3}+$ heat + wastage

\section{End products and Waste Handling:}

The end products from this whole process are biogas, biomethane, and carbon dioxide. Biogas is a product that can be used for producing electricity just like natural gas. Biomethane is used for the same purpose and also very economical. Carbon dioxide is freely used in fertilization. After producing these products, the wastage of the digestion process is diminished.

\section{GAS ESTIMATION}

When the organic materials are collected in one space that is mixer solids and liquids. That wastage consists of volatile solids and ash. Further volatile solids are a combination of biodegradable volatile solids (BVS) and refractory volatile solids (RVS) with some impurities. Refractory volatile solids take a long time to digest. The gas estimation is biodegradable volatile solids as estimated by the following formula [28]:

$\mathrm{BVS}=$ Organic materials $\% *(1-$ mositure $\%) * \mathrm{VS} \% * \mathrm{BVS}$ in VS \%

After the BVS calculation the gas is gas estimated in lbs from the following formula:

BVS Gas $=$ BVS $*$ BVS $\%$ into gas.

\section{END PRODUCTS AND THEIR COMPARISON WITH OTHER RESOURCES}

There are three available options to deal with organic wastage. The first one is to bury it, the second is to burn it and the third is to digest it. Anaerobic digestion is a very useful option and profitable also, therefore a brief review of all options is demonstrated in Table IV.

TABLE IV

DIFFERENT TECHNOLOGIES TO TREAT ORGANIC WASTAGE

\begin{tabular}{|l|l|l|l|l|}
\hline $\begin{array}{l}\text { Sr. } \\
\text { No }\end{array}$ & Technology & $\begin{array}{l}\text { Global } \\
\text { Impact } \\
\text { recovery }\end{array}$ & $\begin{array}{l}\text { Eertilizer } \\
\text { Output }\end{array}$ \\
\hline $\mathbf{1 .}$ & Landfilling & $\begin{array}{l}\text { Leachate } \\
\text { effects }\end{array}$ & $\begin{array}{l}\text { Very low } \\
\text { (Gas } \\
\text { Extraction) }\end{array}$ & None \\
\hline $\mathbf{2 .}$ & Compositing & $\begin{array}{l}\text { Damage } \\
\text { to the } \\
\text { ozone } \\
\text { layer }\end{array}$ & None & None \\
\hline
\end{tabular}




\begin{tabular}{|l|l|l|l|l|}
\hline 3. & Incineration & $\begin{array}{l}\text { Toxic } \\
\text { Ash }\end{array}$ & $\begin{array}{l}\text { Some energy } \\
\text { but mostly } \\
\text { waster }\end{array}$ & None \\
\hline $\mathbf{4 .}$ & $\begin{array}{l}\text { Aerobic } \\
\text { system }\end{array}$ & $\begin{array}{l}\text { Energy } \\
\text { loss }\end{array}$ & $\mathrm{CO}_{2}$ \& Water & None \\
\hline $\mathbf{5}$ & $\begin{array}{l}\text { Anaerobic } \\
\text { Digestion }\end{array}$ & $\begin{array}{l}\text { Total } \\
\text { recovery } \\
\text { of power }\end{array}$ & $\begin{array}{l}\text { Maximum } \\
\text { Energy }\end{array}$ & $\begin{array}{l}\text { Clean } \\
\text { fertilizer }\end{array}$ \\
\hline
\end{tabular}

It is cleared that from the Anaerobic digestion process the maximum recovery is achieved. This recovery has been attained by producing biogas, biomethane, and clean fertilizer.

\section{A. Biogas}

Biogas comprises of $70 \%$ methane gas, $30 \%$ carbon dioxide along with minor impurities. This gas is very useful to produce electricity and can be used the same as natural gas. The cost analysis of biogas with other products is given in Table $\mathrm{V}$. This analysis is done in Pakistani Rupees.

TABLE V

COMPARISON TABLE OF BIOGAS WITH OTHER FUELS

\begin{tabular}{|l|l|l|l|}
\hline $\begin{array}{c}\text { Sr. } \\
\text { No }\end{array}$ & \multicolumn{1}{|c|}{ Items } & \multicolumn{1}{|c|}{ Quantity } & Cost in Rupees \\
\hline $\mathbf{1 .}$ & LPG & $\begin{array}{l}\text { A cylinder of } \\
19 \mathrm{~kg}\end{array}$ & RS.2000 \\
\hline $\mathbf{2 .}$ & Fuel Wood & $40 \mathrm{~kg}$ & RS.1500 \\
\hline $\mathbf{3 .}$ & $\begin{array}{l}\text { Chemical } \\
\text { Fertilizer }\end{array}$ & $50 \mathrm{Kg}$ & RS.3000 \\
\hline $\mathbf{4 .}$ & Bio Gas & $\begin{array}{l}\text { Depend on } \\
\text { availability }\end{array}$ & $\begin{array}{l}\text { After the initial } \\
\text { cost, free }\end{array}$ \\
\hline
\end{tabular}

\section{B. Biomethane}

Biomethane is profitable and very useful to fulfill the energy requirements. As mentioned in Table VI that biodiesel performance is not only below from biomethane and not so much benefit from an economical point of view. Biodiesel is a fuel that is produced from crops. An estimate of the distance covered by the Vehicles by exploiting different fuel produced from the crops are summarized in Table VI.

TABLE VI

DISTANCES COVERED BY THE VEHICLE BY USING DIFFERENT FUELS

\begin{tabular}{|l|l|l|l|}
\hline $\begin{array}{c}\text { Sr. } \\
\text { No. }\end{array}$ & \multicolumn{1}{|c|}{ Fuel } & \multicolumn{1}{|c|}{$\begin{array}{c}\text { Fuel } \\
\text { Production }\end{array}$} & \multicolumn{1}{|c|}{$\begin{array}{c}\text { Distance } \\
\text { Traveled }\end{array}$} \\
\hline $\mathbf{1 .}$ & Diesel or petrol & 650 Litters & $\begin{array}{l}40-45 \\
\text { kilometer }\end{array}$ \\
\hline $\mathbf{2 .}$ & $\begin{array}{l}\text { Biodiesel from } \\
\text { rapeseed oil }\end{array}$ & 650 Litters & $\begin{array}{l}30-35 \\
\text { kilometer }\end{array}$ \\
\hline 3. & Bioethanol & 1250 Litters & $\begin{array}{l}25-30 \\
\text { kilometer }\end{array}$ \\
\hline
\end{tabular}

\begin{tabular}{|l|l|l|l|}
\hline 4. & $\begin{array}{l}\text { Biodiesel from } \\
\text { sunflower oil }\end{array}$ & 2000 Litters & $\begin{array}{l}35-40 \\
\text { kilometer }\end{array}$ \\
\hline $\mathbf{5 .}$ & Biomethane & $1800 \mathrm{Kgs}$ & $\begin{array}{l}50-55 \\
\text { kilometer }\end{array}$ \\
\hline
\end{tabular}

\section{Carbon dioxide and clean fertilizer}

Carbon dioxide is also valuable gas because of its use in different products. This gas can be used as a solvent, carbonation of drinks, decaffeination of coffee, food production in greenhouses, oil extraction, freezing or chilling of food products, and fire extinguisher systems. Further, it can be used as clean fertilizer.

\section{RESULTS AND DISCUSSION}

The end product estimation is shown in Figure. 4 where the aerobic system results are very poor as compared to the proposed system. The end products LPG, Fuelwood, chemical fertilizer, and biogas produce $19 \mathrm{~kg}, 40 \mathrm{~kg}, 50 \mathrm{~kg}$, $30 \mathrm{~kg}$ respectively. In the aerobic system, this is not even half of the proposed system.

The ammonia CODp, sugar TAN, proteins TOC, and organic inserts NORg are $-1.29,-1,-2.43$, and 0.9 respectively. These parameters are optimized and improved as compared to [29]. For example, ammonia CODp should be minimum as it is -1.29 instead of -1.0 in [29]. Similarly, organic inserts NORg is also improved to 0.9 .

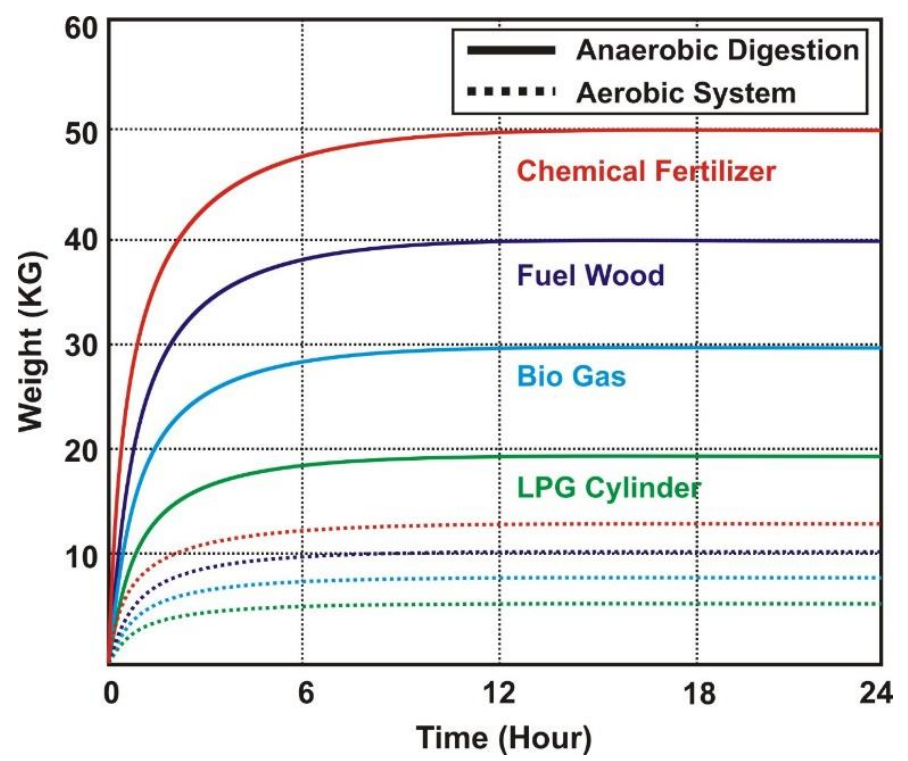

Figure. 4. Anaerobic Digestion vs Aerobic system comparison

\section{CONCLUSION}

Organic fuel is a clean source of domestic energy that is socially acceptable for the community. Rural areas always depend on crops, dairy, and poultry products. The wastage from rural areas and municipal committees are key products for producing organic power. In this 
paper, an analysis of an anaerobic digestion plant producing LPG, fuelwood, chemical fertilizer, and biogas was carried out as a function of the amount of ammonia CODp, sugar TAN, proteins TOC, and organic inserts NORg. This study is based on wastage available in a daily routine and compared with existing models. The plant is developed in different optimizing steps as the Toxicity of Ammonia is reduced by adding organic wastage with a higher ratio of organic materials. Similarly, the optimization of nutrients is done by starting to insert chemical nutrients or adding wastage with a higher ratio of nutrients. The organic overloading and excess of solids are also considered in this research. The system turned out to efficient when the percentage of the end products is more than doubled in the aerobic system.

The suggested layout for the anaerobic digestion process is the best option to get maximum and overall energy from the wastage. The outcomes from that system are not only powerful but also efficient, more applicable, and more beneficial for human beings. The benefits from these end products are: can use as vehicles fuel, clean fertilizer, replacement of fossil fuels, reducing the usage of LPG gas, and conversion of specially grown crops into organic fuel. All these products are very also beneficial from an economical point of view.

\section{REFERENCES}

[1] Junyan Zhao, Junkui Zhang, Siqi Jia, Qi Li, Yue Zhu "A MapReduce framework for on-road mobile fossil fuel combustion CO2 emission estimation" Committees of "2011 19th International Conference on Geoinformatics" DOI: 10.1109/GeoInformatics.2011.5980759

[2] Rao M. Asif, Jamshaid Hamid, Jehangir Arshad, Ateeq Ur Rehman, M. Tariq Sadiq, and Sohaib Tahir, "Design and Analysis of Robust Fuzzy Logic MPPT Based Isolated Photovoltaic Energy System", Engineering Reports, vol. 2, no. 9, 2020; 2:e12234. doi: 10.1002/eng2.12234

[3] A. M. Pollard and R. E. Blanchard, "A hybrid biogas system for Kolkata," 2014 1st International Conference on Non Conventional Energy (ICONCE 2014), Kalyani, 2014, pp. 111-116.

[4] A. Hassan, A. U. Rehman, N. Shabbir, S. R. Hassan, M. T. Sadiq and J. Arshad, "Impact of Inertial Response for the Variable Speed Wind Turbine," 2019 International Conference on Engineering and Emerging Technologies (ICEET), Lahore, Pakistan, 2019, pp. 1-6, doi: 10.1109/CEET1.2019.8711826.

[5] Ateeq Ur Rehman, Rao Muhammad Asif, Rizwan Tariq, Ahmad Javed "GSM based Solar Automatic Irrigation System using Moisture, Temperature and Humidity Sensors" 5th International Conference on Engineering Technology \& Technopreneurship (ICE2T), Kuala Lumpur, Malaysia, 18-20 September 2017, pp. 1-4, DOI: 10.1109/ICE2T.2017.8215945.

[6] Jehangir Arshad, Rizwan Tariq, Saqib Saleem, Ateeq Ur Rehman and A. S. H Mudassir Munir, Noorbakhsh Amiri Golilarz, "Intelligent greenhouse monitoring and control scheme: An arrangement of Sensors, Raspberry Pi based Embedded System and IoT platform," Indian Journal of
Science and Technology, vol. 13, no. 27, pp. 2811-2822, 2020.

[7] A. Hassan et al., "A Wirelessly Controlled Robot-based Smart Irrigation System by Exploiting Arduino," Journal of Robotics and Control (JRC), vol. 2, no. 1, pp. 29-34, 2021.

[8] Sadiq MT, Shabbir N, Kulesza WJ. Spectral subtraction for speech enhancement in modulation domain. International Journal of Computer Science Issues (IJCSI). 2013 Jul 1;10(4):282.

[9] J. Arshad et al., “A Novel Remote User Authentication Scheme by using Private Blockchain-Based Secure Access Control for Agriculture Monitoring," in 2020 International Conference on Engineering and Emerging Technologies, ICEET 2020, 2020, pp. 1-9.

[10] B. Deepanraj, V. Sivasubramanian, S. Jayaraj "Concentration Influence on Biogas Yield from Food Waste in an Anaerobic Batch Digester" International Conference and Utility Exhibition 2014 on Green Energy for Sustainable Development (ICUE 2014).

[11] M. T. Sadiq, X. Yu, Z. Yuan, F. Zeming, A. U. Rehman, I. Ullah, et al., "Motor imagery EEG signals decoding by multivariate empirical wavelet transform-based framework for robust brain-computer interfaces", IEEE Access, vol. 7, pp. 171431-171451, 2019.

[12] M. T. Sadiq et al., "Motor Imagery EEG Signals Classification Based on Mode Amplitude and Frequency Components Using Empirical Wavelet Transform," IEEE Access, vol. 7, pp. 127678-127692, 2019.

[13] A. M. Furqan Durrani, A. U. Rehman, A. Farooq, J. A. Meo, and M. T. Sadiq, "An automated waste control management system (AWCMS) by using Arduino," in 2019 International Conference on Engineering and Emerging Technologies, ICEET 2019, 2019.

[14] A. U. Rehman, R. A. Naqvi, A. Rehman, A. Paul, M. T. Sadiq, D. Hussain "A Trustworthy SIoT Aware Mechanism as an Enabler for Citizen Services in Smart Cities" in Electronics 2020, vol. 9, no. 6, 918. doi: 10.3390/electronics9060918

[15] A. U. Rehman, J. Aimin, A. Rehman, A. Paul, S. Din, M. T. Sadiq, "Identification and Role of Opinion Leaders in Information Diffusion for Online Discussion Network" in Journal of Ambient Intelligence and Humanized Computing, 2020. doi: 10.1007/s12652-019-01623-5

[16] R. A. Naqvi, M. Arsalan, A. Rehman, A. U. Rehman, W.-K. Loh, and A. Paul, "Deep Learning-Based Drivers Emotion Classification System in Time Series Data for Remote Applications," Remote Sensing, vol. 12, no. 3, p. 587, Feb. 2020.

[17] Haider Arslan, Ateeq Ur Rehman, Noman Shabbir, Syed Rizwan Hassan and Irfan Haider, "A Three Stage Load Sharing Routing Algorithm to Increase Lifetime of Cognitive Radio Sensor Networks", Journal of Communications, vol. 12, no. 5, pp. 254-260, 2017.

[18] M. S. Islam, A. Islam and M. Z. Islam, "Variation of biogas production with different factors in poultry farms of Bangladesh," 2014 3rd International Conference on the Developments in Renewable Energy Technology (ICDRET), Dhaka, 2014, pp. 1-6.

[19] F. Khan, M. A. B. Siddiqui, A. U. Rehman, J. Khan, M. T. S. A. Asad and A. Asad, "IoT Based Power Monitoring System for Smart Grid Applications," 2020 International Conference on Engineering and Emerging Technologies (ICEET), Lahore, Pakistan, 2020, pp. 1-5, doi: 10.1109/ICEET48479.2020.9048229.

[20] A. Ur Rehman, M. Tariq Sadiq, N. Shabbir, and G. Abbas Jafri, "Opportunistic Cognitive MAC (OC-MAC) Protocol 
for Dynamic Spectrum Access in WLAN Environment," International Journal of Computer Science Issues (IJCSI), vol. 10, no. 6, pp. 45-51, 2013.

[21] A. U. Rehman, A. Jiang, A. Rehman, and A. Paul, "Weighted Based Trustworthiness Ranking in Social Internet of Things by using Soft Set Theory," in 2019 IEEE 5th International Conference on Computer and Communications (ICCC), 2020, pp. 1644-1648.

[22] B. Masood, M. A. Khan, et al. "Investigation of Deterministic, Statistical and Parametric NB-PLC Channel Modeling Techniques for Advanced Metering Infrastructure", Energies, vol. 13, no. 12, 3098, 2020, doi: 10.3390/en 13123098

[23] P. Capaldi, A. Daliento and R. Rizzo, "An innovative $10 \mathrm{~kW}$ microcogenerator suitable for off grid application and fed with syngas or biogas," 2014 49th International Universities Power Engineering Conference (UPEC), Cluj-Napoca, 2014, pp. 1-6.

[24] Rao Muhammad Asif, Adnan Yousaf, Ateeq Ur Rehman, Hafiz M. Ashraf, and Saif Ur Rehman "Real Time Extra Economic Dispatch For Renewable Energy Uncertainty Over IEEE Bus Bar" in IEEEP New Horizon Journal, Volume 97-100, page 9-16, December 2018, ISSN: 22263659.

http://www.ieeepnhrj.org/index.php/ieeep/article/vie $\mathrm{w} / 3$

[25] M. R. A. Mamun and S. Torii, "Anaerobic co-digestion of cafeteria, vegetable and fruit wastes for biogas production," 2014 International Conference on Renewable Energy Research and Application (ICRERA), Milwaukee, WI, 2014, pp. 369-374.

[26] Y. Manabe et al., "Cooperative control of energy storage systems and biogas generator for multiple renewable energy power plants," 2014 Power Systems Computation Conference, Wroclaw, 2014, pp. 1-7.

[27] S. R. Hassan, A. U. Rehman, N. Shabbir, and A. Unbreen, "Comparative Analysis of Power Quality Monitoring Systems", NFC IEFR Journal of Engineering And Scientific Research, vol. 7, no. 1, pp. 19-23, 2020, doi: 10.24081/nijesr.2019.1.0004 Available at: http://nijesr.com/ojs/index.php/archive/article/view/249.

[28] D. C. Augenstein, D. L. Wise, R. L. Wentworth, "Fuel Gas Recovery from controlled landfilling of municipal wastes", Massachusetts Institute of Technology, Cambridge, Mass. 02139 (U.S.A.), 1976

[29] U. Zaher1, P. Buffiere, J-P Steyer, S. Chen1 et al., "A Procedure to Estimate Proximate Analysis of Mixed Organic Wastes", DOI: 10.2175/106143008X370548, Water Environment Research 81(4):407-15, 2009

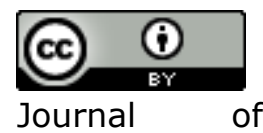

$$
\text { Applied and Emerging }
$$

